\title{
Foliar Nematode Aphelenchoides spp. (Nematoda: Aphelenchida: Aphelenchoididae) ${ }^{1}$
}

\author{
Lindsay Wheeler and William T. Crow ${ }^{2}$
}

\section{Introduction}

There are several nematode genera that feed on plant stems and foliage, including Aphelenchoides, Bursaphelenchus, Anguina, Ditylenchus, and Litylenchus. Herein, the common name foliar nematode is used for plant-feeding nematodes in the genus Aphelenchoides, specifically Aphelenchoides besseyi, Aphelenchoides fragariae, and Aphelenchoides ritzemabosi. While most members of Aphelenchoides are fungivorous (feed on fungi), these three species have populations that are facultative plant-parasites and feed on live plant tissue. Ten other species of Aphelenchoides are recognized as facultative plant-parasites, but these are not as common or as economically significant as the aforementioned species. Unlike most plant-parasitic nematodes, foliar nematodes infest the aerial portions of plants rather than dwelling strictly in soil and roots. Damage from foliar nematodes can reduce yield in food crops and ruin the appearance and marketability of ornamentals.

\section{Distribution}

Fungivorous Aphelenchoides are found on every continent, including Antarctica (Maslen 1979), and the three main species of foliar parasites can be found globally wherever horticultural crops are grown (EPPO Global Database https://gd.eppo.int). The complete scope of their range is not fully understood, because their interactions with agricultural hosts have been better documented than the vast array of ornamental and wild plants they can conceivably infect. Whether they are an introduced pest in Florida is unknown; given their cosmopolitan distribution, it is difficult to trace the origins of foliar nematodes back to one native region.

\section{Description}

The family Aphelenchida includes several genera of plant-parasitic nematodes, but the two most important are Aphelenchoides and Bursaphelenchus, the latter of which causes vascular disease in pine trees and palms. These nematodes are slender and small, even by nematode standards, averaging around a millimeter in length and less than 20 microns in width. For perspective, that is roughly the thickness of a dime and about a quarter the width of a human hair, respectively.

The median bulb, which is the pumping structure of the esophagus, is larger in Aphelenchida than that of plant-parasites in the order Tylenchida, appearing more rectangular than round (Figure 1). The duct for enzyme secretion (dorsal esophageal gland orifice) connects to the esophageal lumen at the base of the stylet in most plantparasitic nematodes, but in Aphelenchida this duct empties into the esophageal lumen within the median bulb.

Like other plant-parasitic and fungivorous nematodes, Aphelenchoides bear a stylet: a hardened, spear-like mouthpart for puncturing plant and fungal hypha cells; however, the stylet of Aphelenchoides is much smaller than that of most

1. This document is EENY-749, one of a series of the Entomology and Nematology Department, UF/IFAS Extension. Original publication date February 2020. Visit the EDIS website at https://edis.ifas.ufl.edu for the currently supported version of this publication. This document is also availabe on the Featured Creaturs website at http://entomology.ifas.ufl.edu/creatures.

2. Lindsay Wheeler; and William T. Crow, associate professor; Entomology and Nematology Department, UF/IFAS Extension, Gainesville, FL 32611.

The Institute of Food and Agricultural Sciences (IFAS) is an Equal Opportunity Institution authorized to provide research, educational information and other services

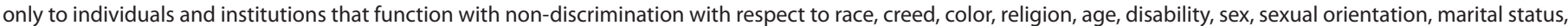

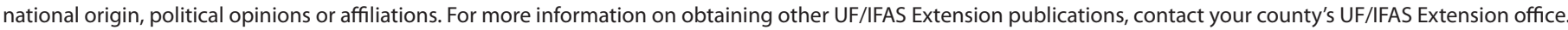
U.S. Department of Agriculture, UF/IFAS Extension Service, University of Florida, IFAS, Florida A \& M University Cooperative Extension Program, and Boards of County Commissioners Cooperating. Nick T. Place, dean for UF/IFAS Extension. 
other plant-parasites (Figure 1). Their stylets have small basal knobs, a feature that can be used to separate them from the closely related fungivorous genus Aphelenchus, which lacks knobs. Aphelenchoides reproduce primarily by amphimixis, and males are common. The vulva of the female is located near $2 / 3$ the body length from the anterior. Females have a single, prodelphic (anteriorly outstretched) ovary and a post-uterine sac, while males have prominent, thorn-shaped spicules (paired, cuticularized copulatory structures) (Figure 2).

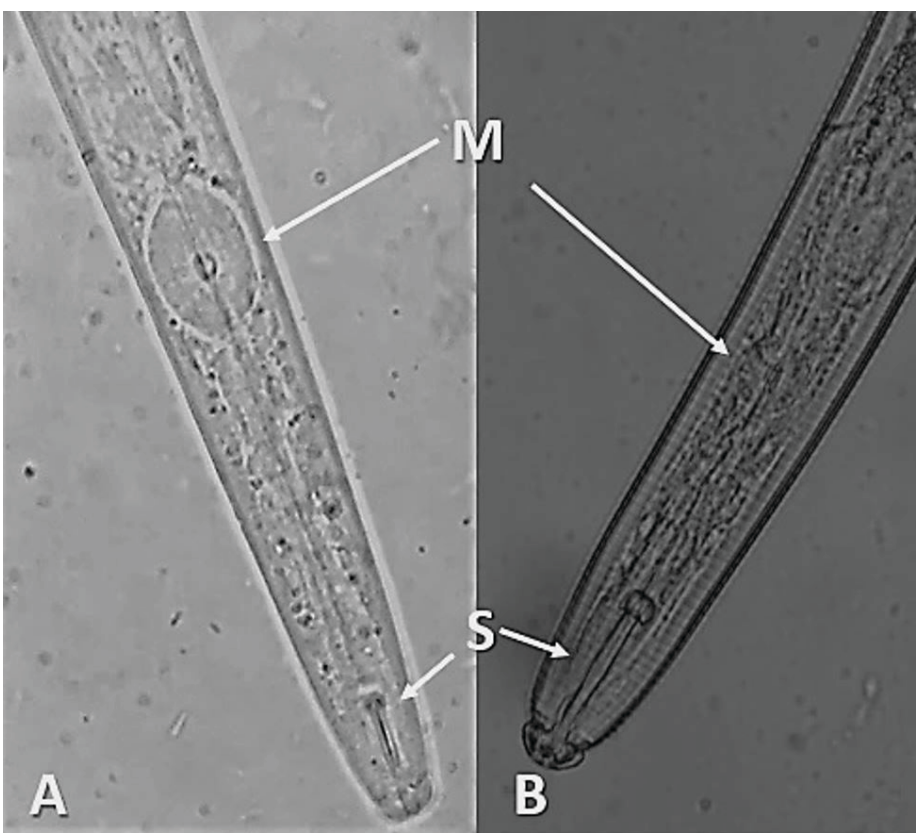

Figure 1. Anterior of an aphelenchid nematode, Aphelenchoides besseyi (A) and a tylenchid nematode, Hoplolaimus sp. (B). The median bulb (M) of aphelenchids are larger and more square-shaped than those of tylenchids. The stylet (S) of aphelenchids and other fungivores tend to be smaller than those of most obligate plant-parasites.

Credits: Lindsay Wheeler (A), and William T. Crow (B), UF/IFAS

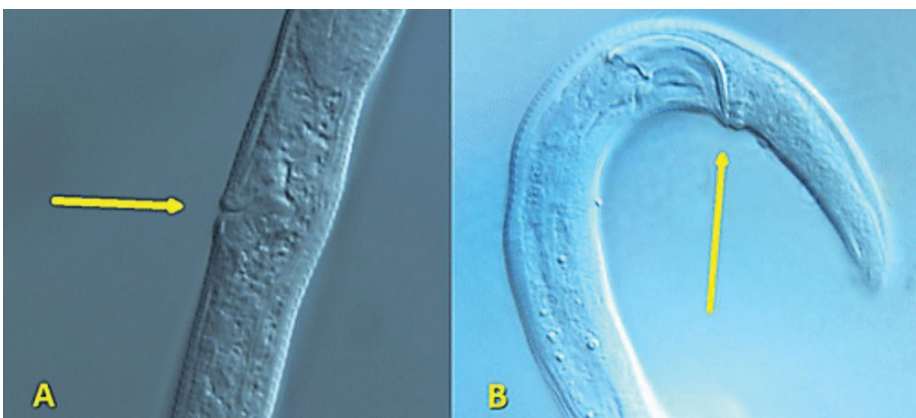

Figure 2. Reproductive organs of Aphelenchoides besseyi. Females (A) of Aphelenchoides sp. lack the vulval flap found in Bursaphelenchus sp. Males (B) of Aphelenchoides sp. lack the bursa found in Bursaphelenchus sp.

Credits: Lindsay Wheeler, UF/IFAS

The females and males of Aphelenchoides differ from their other close relative, Bursaphelenchus, by lacking a vulval flap and bursa (copulatory grasping structures), respectively (Figure 2). A distinctive, though difficult to observe, physical feature of Aphelenchoides is the mucro, which is a miniscule projection from the tip of the nematode's tail (Figure 3). Different species may have a mucro with a single-pointed tip or one that flares into multiple points, and this is commonly used as a diagnostic feature. Foliar nematodes tend to exhibit far more physical activity than their soil-dwelling, plant-parasitic counterparts. Numerous, rapidly undulating roundworms (as seen in this video) can be extracted by allowing shredded leaves to soak in water for a day or two, but a microscope is still necessary to observe them. If species identification in needed, the UF/IFAS Nematode Assay Lab can identify Aphelenchoides and other nematodes to species using morphological and molecular methods.

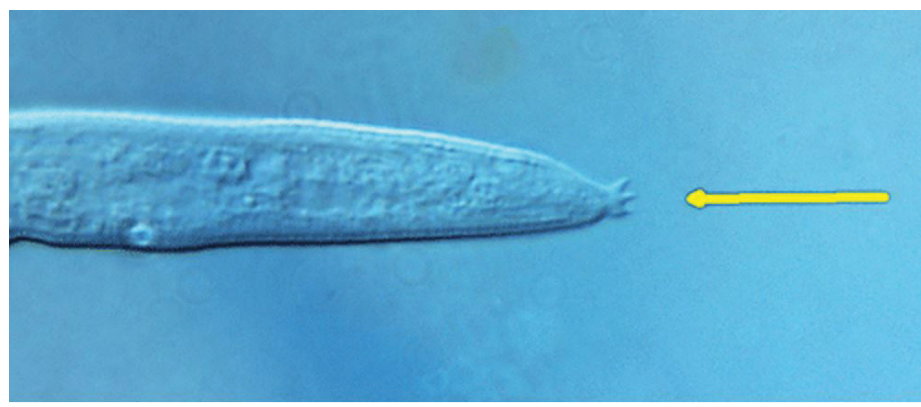

Figure 3. Three-pointed mucro on the tail tip of Aphelenchoides besseyi.

Credits: Lindsay Wheeler, UF/IFAS

\section{Life Cycle and Biology}

On plants, foliar nematodes are known to feed both ectoparasitically (on the host surface) or endoparasitically (within plant tissue). As ectoparasites, foliar nematodes often inhabit the tightly folded tissue of leaf and flower buds. As endoparasites, they enter leaves through open stomata to lay eggs among the cells of the mesophyll. As with all nematodes, Aphelenchoides molt their cuticle once while still in their egg and three more times before reaching adulthood. The second-stage juveniles (J2) hatch and begin feeding on the surrounding cells. Once foliar nematodes grow to the fourth-stage juvenile (J4) or adult stage, they can migrate out of the leaf and travel across the outside of the plant when a film of water is present, such as after rain, irrigation, or morning dew (Wallace 1960).

Some of the migrating nematodes may be splashed onto neighboring plants, reinfest the original plant in a different location, or travel upward toward the plant's reproductive structures (flowers, panicles, etc.). Although they rely on moisture for active dispersal, foliar nematodes are well adapted to survive when conditions are very dry (desiccation). If allowed to desiccate gradually, these nematodes can remain dormant in seeds or dry plant tissue until they are rehydrated by moist conditions, thereby returning to an 
active and infective state (French and Barraclough 1962). The rice white tip foliar nematode Aphelenchoides besseyi and the chrysanthemum foliar nematode Aphelenchoides ritzemabosi have been shown to remain viable in this state of anhydrobiotic dormancy for 20 to 36 months (French and Barraclough 1962; Huang and Huang 1974).

\section{Hosts}

Foliar nematodes have been documented in association with over 700 species of plants, which include at least 126 families spanning monocots and dicots, gymnosperms and angiosperms, and even ferns, liverworts, and clubmosses (Sánchez-Monge 2015). The host ranges of individual Aphelenchoides species often overlap, and thus one plant group may be a suitable host for multiple species of foliar nematode (Kohl 2011). In addition to plant hosts, foliar nematodes are capable of feeding on fungi. This unusual degree of dietary diversity can make management challenging, because methods such as crop rotation will not deny these nematodes a food source.

\section{Economic Importance}

While having to replace plants in a landscape or small garden is frustrating, foliar nematodes create far more expensive problems in nursery production and food crops. The practical and economic importance of food production may be intuitive, but the $\$ 4.6$ billion in wholesale value that the US floriculture (non-agricultural plant production) industry generates is also worth noting (Anonymous 2019). Foliar nematodes can spread rapidly through operations where plants are somewhat crowded and are irrigated by overhead sprinklers.

It has been reported that certain organophosphate and carbamate insecticides previously used in nurseries provided incidental control of foliar nematodes (Jagdale and Grewal 2002); however, most of these pesticides are no longer registered for use on floricultural crops, so outbreaks of foliar nematodes are becoming more common. Similarly, recent outbreaks of crimp disease (described below) in Florida strawberry production has been attributed to the loss of methyl bromide fumigation as a management option in transplant nurseries (Desaeger and Noling 2017). It is difficult to predict the financial impact that the loss of these management tools may have on the plant industry as a whole, and data regarding current losses is largely unavailable.

The most commonly encountered symptom of endoparasitic feeding is a patchwork browning of foliar tissue
(Figure 4). This pattern suggests the nematodes are unable to burrow through leaf veins, requiring them to exit the leaf when food is exhausted within the vein-bordered area and reenter the host elsewhere. The lesions left behind may appear geometric, streak-like, or as speckles depending on the venation patterns of the host plant. On ferns, browning of the pinnules may occur on only one side of the costas (Figure 5). Plants may also exhibit a lack of vigor due to heavy infestation, such as stunted growth and a thin canopy.

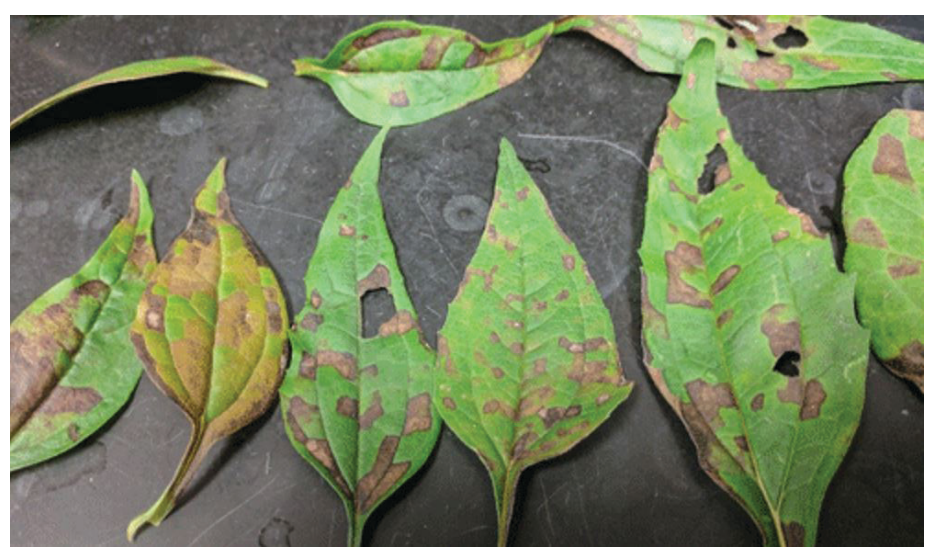

Figure 4. Foliar nematodes cause vein-delimited discoloration, such as the geometric lesions on these echinacea leaves.

Credits: William T. Crow, UF/IFAS

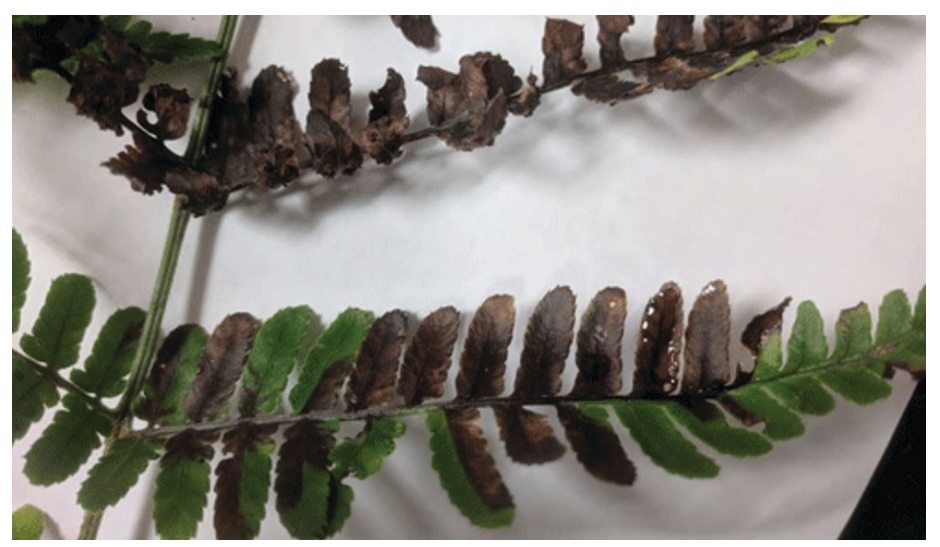

Figure 5. On ferns, foliar nematodes can cause lesions confined to individual pinnae or lobes of pinnae.

Credits: William T. Crow, UF/IFAS

Symptoms may vary between host crops, even when infected with the same species of foliar nematode. For example, white tip disease of rice and green stem and foliar retention syndrome of soybean are both caused by Aphelenchoides besseyi (Figure 6). In rice, white tip disease induces chlorotic whitening of the leaf tips, extending 3 to $5 \mathrm{~cm}$ down the leaf, which is its diagnostic symptom. Damage to the panicles can result in a significant yield loss (de Jesus et al. 2016). In Brazil, this same species has been recently identified as a major pest of soybean, where it disrupts harvest by causing plants to remain green when they should senesce (Meyer et al. 2017). In addition to a single species causing different symptoms on two hosts, 
more than one species can be associated with a single host Aphelenchoides besseyi and Aphelenchoides fragariae are known to cause crimping disease symptoms in strawberries, where the leaves grow crumpled and distorted, and the fruit is likewise stunted and deformed (Figure 7) (Desaeger and Noling 2017).

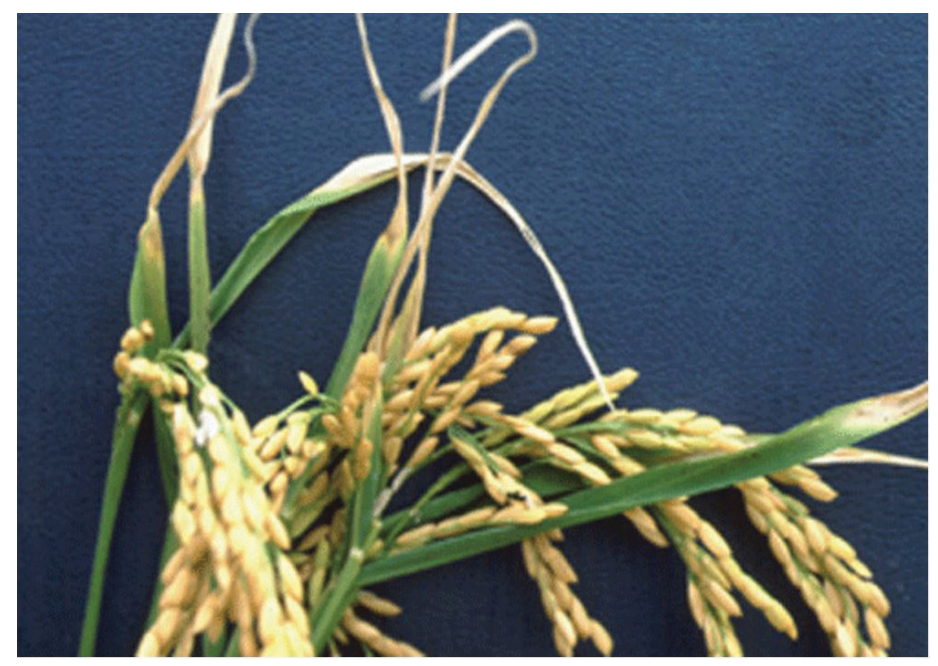

Figure 6. White tip disease caused by Aphelenchoides besseyi, which is characterized by chlorotic leaf tips.

Credits: E. C. McGawley, Louisiana State University

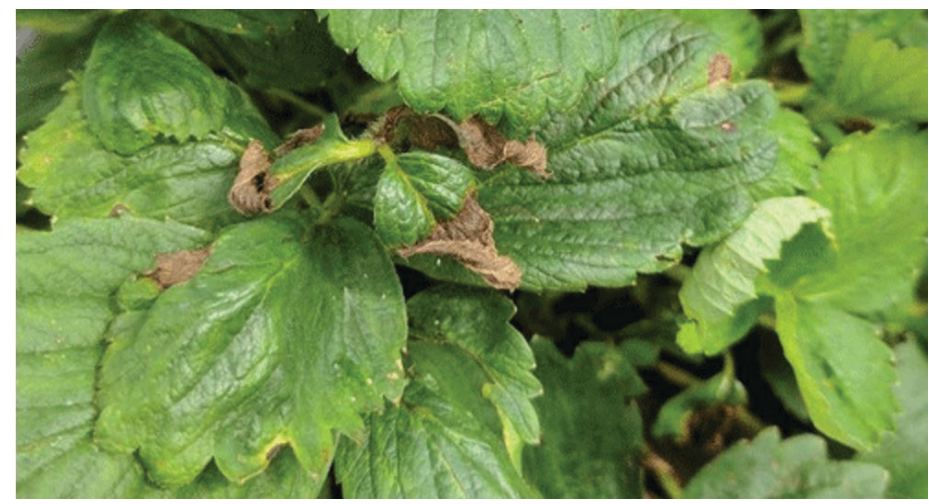

Figure 7. Strawberry leaf crimp caused by Aphelenchoides besseyi. Credits: William T. Crow, UF/IFAS

\section{Management}

Little can be done to salvage a plant that is already infested, because the nematodes may have spread throughout the foliage by the time the symptoms become noticeable. Presently, sanitation is the best means of halting the spread of foliar nematodes. This means keeping plants well-spaced, using drip rather than overhead irrigation, and disposing of dead leaves rather than utilizing them as mulch or allowing them to remain underneath the plant canopy. It is also important to be mindful of irrigation sources, because pond-sourced irrigation may transport nematodes from infested pond weeds.
Some success has been achieved using hot-water treatment or a succession of wetting and rapid dehydration of seeds, such as with rice, but this is not feasible with all potential hosts (Jagdale and Grewal 2004; Hoshino and Togashi 2000). Very few pesticides are currently labeled for use against foliar nematodes, and research is ongoing to develop new or reformulated products that can effectively manage outbreaks. Beyond rice, there does not appear to be an effort to develop resistant plant cultivars, nor much data on what genes are involved with resistance to foliar nematodes.

\section{Selected References}

Anonymous. 2019. Floriculture Crops 2018 Summary (May 2019). National Agricultural Statistics Service. ISSN: 1949-0917.

de Jesus DS, Oliveira CMG, Roberts D, Blok V, Neilson R, Prior T, Balbino HM, MacKenzie KM, Oliveira RDL. 2016. "Morphological and molecular characterization of Aphelenchoides besseyi and A. fujianensis (Nematoda: Aphelenchoididae) from rice and forage grass seeds in Brazil." Nematology 18: 337-356.

Desaeger J, Noling J. 2017. Foliar or Bud Nematodes in Florida Strawberries. ENY-068. Gainesville, FL: University of Florida Institute of Food and Agricultural Sciences. https://edis.ifas.ufl.edu/in 1184

French N, Barraclough RM. 1962. "Survival of Aphelenchoides ritzemabosi (Schwartz) in soil and dry leaves." Nematologica 7: 309-316.

Hoshino S, Togashi K. 2000. "Effect of water-soaking and air-drying on survival of Aphelenchoides besseyi in Oryza sativa seeds." Journal of Nematology 32: 303-308.

Huang CS, Huang SP. 1974. "Dehydration and the survival of rice white tip nematode, Aphelenchoides besseyi." Nematologica 20: 9-18.

Jagdale GB, Grewal PS. 2002. "Identification of alternatives for management of foliar nematodes in floriculture." Pest Management Science 58: 451-458.

Jagdale GB, Grewal PS. 2004. "Effectiveness of a hot water drench for the control of foliar nematodes Aphelenchoides fragariae in floriculture." Journal of Nematology 36: 49-53.

Kohl LM. 2011. "Foliar nematodes: A summary of biology and control with a compilation of host range." Plant Health Progress. doi:10.1094/PHP-2011-1129-01-RV. 
Maslen NR. 1979. "Six new nematode species from the maritime Antarctic." Nematologica 25: 288-308.

Meyer M, Favoreto L, Klepker D, Marcelino-Guimarães FC. 2017. "Soybean green stem and foliar retention syndrome caused by Aphelenchoides besseyi." Tropical Plant Pathology 42: 403-409.

Sánchez-Monge A, Flores L, Salazar L, Hockland S, Bert W. 2015. "An updated list of the plants associated with plantparasitic Aphelenchoides (Nematoda: Aphelenchoididae) and its implications for plant-parasitism within this genus." Zootaxa 4013: 207-224.

Wallace HR. 1960. "Observations on the behaviour of Aphelenchoides ritzemabosi in chrysanthemum leaves." Nematologica 5: 315-321. 